\title{
フジコナカイガラムシ性フェロモンの 2 種寄生蜂に対する誘引性
}

\author{
杖田 浩二 * \\ 岐阜県農業技術センター
}

\begin{abstract}
Response of Two Parasitoid Wasps to the Sex Pheromone of Japanese Mealybug, Planococcus kraunhiae. Hirotsugu

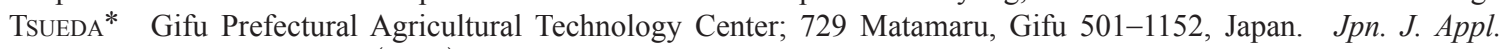
Entomol. Zool. 58: 147-152 (2014)
\end{abstract}

\begin{abstract}
The attraction of two parasitoid wasps, Allotropa subclavata (Muesebeck) and Anagyrus fujikona (Tachikawa), to the sex pheromone of Japanese mealybug, Planococcus kraunhiae (Kuwana), was investigated using a pheromone trap and a blank trap under natural and mating disruption conditions by sex pheromones. Although A. fujikona was caught by the pheromone trap in the control plot, this parasitoid was not caught by the blank trap in the control plot or either trap in the mating disruption plot. On the other hand, A. subclavata was caught by both traps equally in control and mating disruption plots. The prevalence of $A$. fujikona caught by the pheromone trap was similar to that of $P$. kraunhiae male adults. Additionally, the peaks of caught $A$. fujikona corresponded to the prediction of when second and third instar larvae of $P$. kraunhiae would appear. These results suggest that $A$. fujikona was attracted to the sex pheromone, and that the prevalence of this parasitoid could be monitored by a pheromone trap of $P$. kraunhiae.
\end{abstract}

Key words: Parasitoid wasp; Anagyrus fujikona; Allotropa subclavata; attracted to sex pheromone; Planococcus kraunhiae

緒 言

フジコナカイガラムシ Planococcus kraunhiae (Kuwana) は, カキ，ブドウ，カンキツ，イチジクなど果樹の広食性 害虫である (河合, 1980; 柴尾・田中, 2000). カキに扎い て本種は，排泄物に起因するすす病や，加害部が赤化する 火ぶくれ症状など，果実の商品品質を著しく低下させる被 害を引き起こす。本種は，果実とへタの間の隙間や枝幹部 などの粗皮下に寄生しているため散布した薬液が到達しに くいこと, 防除適期である幼虫発生初期の把握が困難なこ とから，薬剤散布による防除が困難な害虫である（上野， 1977). 一方，本種には多様な土着天敵の存在が明らかと なっており，フジコナカイガラクロバチ Allotropa subclavata (Muesebeck) やフジコナカイガラトビコバチ Anagyrus fujikona（Tachikawa）は, 特に有力な天敵寄生蜂と考えら れている (手柴・堤, 2004). 近年フジコナカイガラムシ が多発した要因の一つとして，合成ピレスロイド剂の使用 が有用天敵に悪影響を及ぼし可能性が指摘されており (大政, 1990), 土着天敵の利用は本種の防除に打いて重要 であると考えられる。このことから，寄生蜂の発生時期や

*E-mail: tsueda-hirotsugu@pref.gifu.lg.jp

2013 年 9 月 2 日受領 (Received 2 September 2013)

2014 年 3 月 3 日登載決定 (Accepted 3 March 2014)

DOI: $10.1303 /$ jjaez.2014.147
発生量をモニタリングすることは，農薬散布の影響を回避 し，寄生蜂を効率的に利用するうえで重要と考えられる.

カイガラムシ類は性フェロモンによる交信を行うこと が知られており，近年その構造や成分が解明されつつあ る (Roelofs et al.,1978; Gieselmann et al., 1979; Zada et al., 2003; Zhang and Amalin, 2005). 本種も性フェロモンの主 成分が 2-isopropyliden-5-methyl-4-hexen-1-yl butyrate である ことが解明されており（Sugie et al., 2008）, 性フェロモン を利用した誘引剤が 2012 年に市販され，発生予察に利用 されている，さらに，合成性フェロモンを利用した交信 攪乱法が有効であることも明らかにされている（手柴ら， 2009). 一方，フジコナカイガラムシの近縁種であるミカ ンコナカイガラムシ Planococcus citri (Risso) や, 海外に おけるブドウの重要害虫である Planococcus ficus Signoret のトビコバチ科寄生蜂の 1 種である Anagyrus spec. nov. near pseudococci は，宿主の性フェロモンをカイロモンと して宿主探索に利用することが示されている（Franco et al., 2008). フジコナカイガラムシにも同属の寄生蜂がいるこ とから，それらは宿主の性フェロモンを利用して宿主を探 索している可能性がある。このことは，フジコナカイガラ 
ムシの合成性フェロモンを用いることで，寄生蜂もモニタ

リングできる可能性を示唆している.

そこで筆者は，現地圃場でフジコナカイガラムシの合成 性フェロモンに対する寄生蜂の誘引性を調査するととも に，フェロモントラップによる寄生蜂のモニタリングを 行ったのでここに報告する.

報告に先立ち，寄生蜂の同定抢よび原稿の校閲を賜った 山口県柑きつ振興センターの東浦祥光博士, 有益な助言を 賜った福岡県農業総合試験場の手柴真弓氏および岐阜県農 業経営課鈴木俊郎氏，誘引剤の提供にご協力いただいた島 根県農業技術センターの澤村信生氏扎よび富士フレーバー 株式会社の佐々木力也博士，現地圃場での試験にご協力い ただいた関係者各位に謝意を表する。

\section{材料および方法}

\section{供試誘引剤およびフェロモントラップ}

フジコナカイガラムシの性フェロモンの主成分である 2-isopropyliden-5-methyl-4-hexen-1-yl butyrate ゴムセプタ ムに $0.1 \mathrm{mg}$ 含浸させた誘引剤 (富士フレーバー(株) 製)を 供試した。この誘引剤 1 個を，三角屋根型粘着トラップ (SEトラップ，サンケイ化学(株) 製) の粘着面中央に設置 したものを，フェロモントラップとした．フェロモント ラップは，粘着面が地上約 $1.5 \mathrm{~m}$ の高さとなるよう，カキ の主枝に設置した。誘引剤は約 1 カ月ごとに，粘着板は各 試験において実施した調査ごとに新品と交換した。

試験 1. 性フェロモンの寄生蜂に対する誘引性

岐皁市の現地力キ園 3 圃場（A 固場：面積 $15 \mathrm{a}$ ，北緯 35 度 27.5 分，東経 136 度 43.1 分, B 圃場：同 $12 \mathrm{a}$, 北緯 35 度 27.5 分, 東経 136 度 43.3 分, C 固場: 同 $10 \mathrm{a}$, 北緯 35 度 26.3 分，東経 136 度 42.5 分）に打いて試験を行った。 供試樹の品種は富有とし，樹齢は $\mathrm{A}$ 打よび $\mathrm{C}$ 围場では 35 年生, B 固場では 40 年生の樹が主体であった。各戋場中 央付近の 1 樹に, 上記フェロモントラップと誘引剤を設置 しないトラップ (ブランクトラップ) を，樹幹を中心とす る対極線上に約 $3 \mathrm{~m}$ 程度離して設置し, 粘着板上に捕殺さ れた寄生蜂個体数を種ごとに調査した。調査は 2010 年 6 月から 10 月にかけて, 約 2 週間間隔で 9 回行った。また 両トラップは，調査ごとにそれぞれの位置を交換した。そ れぞれのトラップにおける寄生蜂捕殺数は, Wilcoxonの符 号順位検定法を用いて比較した.

\section{試験 2. 交信攪乱条件下におけるフジコナカイガラムシ} 性フェロモンの寄生蜂に対する誘引性

岐皁市内の現地力キ围場（D 圃場：面積 $15 \mathrm{a}$, 北緯 35 度 27.5 分, 東経 136 度 43.2 分）に扔いて, フジコナカイ ガラムシの交信摫乱条件下に打ける性フェロモンの寄生蜂 に対する誘引性を調査した。戋場を東西で 2 分割し，一方 の区画は手柴ら（2009）に従いフェロモン成分を $3 \mathrm{mg}$ 含
浸させたゴムセプタムを長さ約 $30 \mathrm{~cm}$ のアルミ製針金に 20 個程度通し，これを 1 樹当たり 3 本程度設置すること で $10 \mathrm{a}$ あたりのフェロモン成分投下量を $1 \mathrm{~g}$ とした交信覮 乱区 (以降，覮乱区) とし，もう一方の区画は無処理区と した。供試樹の品種は富有で, 樹齢は35年生が主体であっ た.フェロモントラップとブランクトラップは, 試験 1 と 同様の方法でそれぞれ各区 2 個ずつ設置し，フジコナカイ ガラムシ雄成虫の誘殺数打よび寄生蜂の捕殺数を調査し た。調査期間，調査方法扔よびトラップ位置の交換は，試 験 1 のと打りとした，両区に打けるそれぞれのトラップあ たりのフジコナカイガラムシ雄成虫の総誘殺数打よび寄生 蜂の総捕殺数は, $\chi^{2}$ 検定を用いて比較した。

試験 3. フェロモントラップにおけるフジコナカイガラ ムシ雄成虫誘殺消長およびフジコナカイガラ トビコバチ捕殺消長

岐皁市 $\mathrm{A}$ 围場打よび大野町の現地カキ围場（面積 $10 \mathrm{a}$, 北緯 35 度 27.4 分, 東経 136 度 38.3 分）に扔いて試験を行っ た。供試樹の品種はいずれも富有とした。これら戋場内の 1 樹にフェロモントラップを 1 個設置し，フジコナカイガ ラムシ雄成虫の誘殺数打よびフジコナカイガラトビコバチ 成虫の捕殺数を調査した。調査は 2011 年および 2012 年の 5 月上旬から 10 月下旬にかけて, 約 1 週間間隔で行った.

寄生蜂の捕殺時期とフジコナカイガラムシ齢期との関係 を明らかにするため，澤村・奈良井（2008）に示された各 齢期の発育零点と有効積算温度, 各年次の平均気温 (岐阜 市抢よび揖斐川町のアメダスデータ, 岐皁市; 北緯 35 度 24.0 分, 東経 136 度 45.7 分, 標高 $12.7 \mathrm{~m}$, 揖斐川町; 北 緯 35 度 29.1 分，東経 136 度 34.0 分，標高 $45 \mathrm{~m}$ ）を用い, 雄成虫の誘殺ピークを起点として各齢期の出現予測時期を 算出し，寄生蜂の捕殺時期と比較した.

\section{結果}

試験 1. 性フェロモンの寄生蜂に対する誘引性

$\mathrm{A} ， \mathrm{~B}$ 扎よびC 戋場に設置したフェロモントラップには, フジコナカイガラトビコバチと, フジコナカイガラクロバ チが, 調査期間を通じて捕殺された。 A, B , C 戋場に設置 したフェロモントラップに打けるフジコナカイガラトビコ バチの総捕殺数は，それぞれ 87 頭，130 頭および 31 頭と なった。 そのうち雄成虫の総捕殺数は，それぞれ 6 頭, 4 頭, 2 頭であり, 捕殺個体の大半は雌成虫であった。 一方, ブランクトラップではフジコナカイガラトビコバチはほと んど捕殺されず，フェロモンの有無で有意な差が認められ た (Fig. 1)。フェロモントラップに打けるフジコナカイガ ラクロバチの総捕殺数は, 各戋場で 100〜200 頭となった. またブランクトラップでも同様に捕殺され，フェロモンの 有無による差はなかった (Fig. 1). 

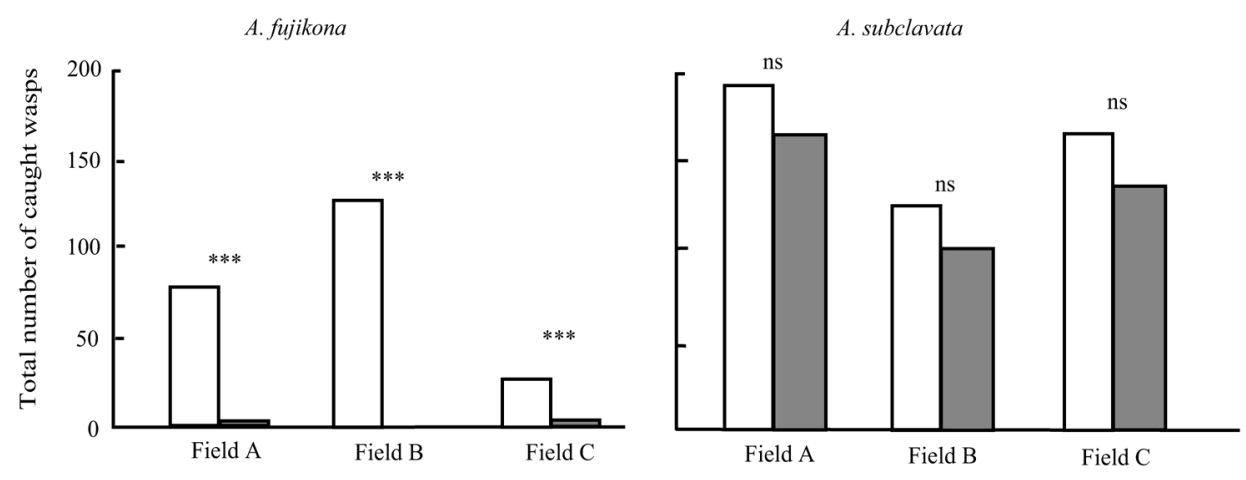

Trap with pheromone lure

$\square$ Blank trap

Fig. 1. Total numbers of A. fujikona and A. subclavata female adults caught in the pheromone trap and blank trap from June to October, 2010. The locations of the pheromone trap and blank trap were changed in each investigation. Asterisks $\left({ }^{* * *}\right)$ indicate a significant difference between two traps (Wilcoxon's signed rank test, $p<0.001$ ); ns $=$ no significant difference.

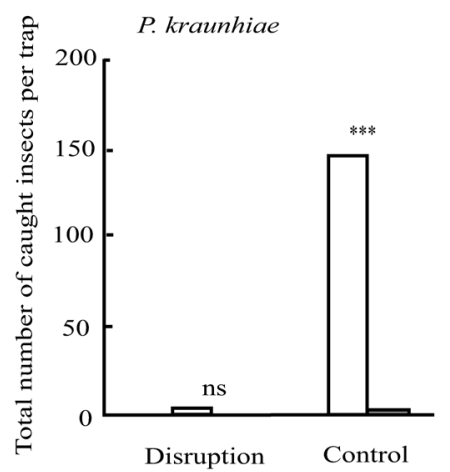

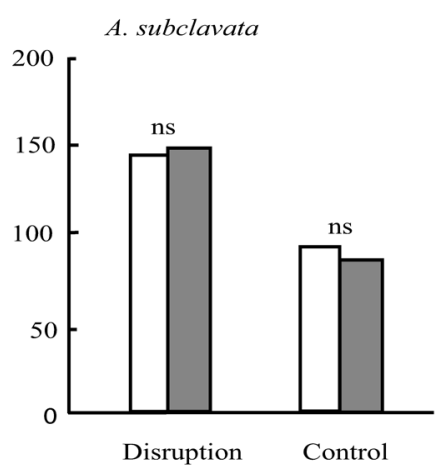

Blank trap

Fig. 2. Total numbers of $P$. kraunhiae male and female adults of A. fujikona and A. subclavata caught in the pheromone trap and blank trap under natural and mating disruption conditions by sex pheromones from June to October, 2010. The locations of the pheromone trap and the blank trap were changed in each investigation. Asterisks $\left({ }^{* * *}\right)$ indicate a significant difference between two traps (chi square test, $p<0.001$ ); ns $=$ no significant difference.

\section{試験 2. 交信攪乱条件下における性フェロモンの寄生蜂 に対する誘引性}

$\mathrm{D}$ 圑場の攪乱区におけるフジコナカイガラムシ雄成虫の トラップあたりの総誘殺数は，フェロモントラップが 3.5 頭, ブランクトラップが 0 頭となり, 有意な差はなかった. 一方無処理区に打ける総誘殺数は，フェロモントラップが 143.5 頭，ブランクトラップが 2.5 頭となり，有意な差が 認められた (Fig. 2). フジコナカイガラトビコバチの捕殺 は，フジコナカイガラムシ雄成虫の誘殺と同様の傾向を示 した。すなわち，攪乱区ではいずれのトラップにもほとん ど捕殺されなかったが (フェロモントラップ 0.5 頭, ブラ ンクトラップ 0 頭), 無処理区に打ける総捕殺数は, フェ ロモントラップで19頭, ブランクトラップで 1.0 頭となり, 有意な差が認められた (Fig. 2). 捕殺されたフジコナカイ ガラトビコバチは雌成虫が大半で，雄成虫は無処理区に設
置した両トラップに 1 頭ずつ捕殺されただけであった. フ ジコナカイガラクロバチのトラップあたりの総捕殺数は, 攪乱区のフェロモントラップで 142 頭, ブランクトラップ で 146 頭，無処理区でもそれぞれ 82.5 頭, 70.5 頭となり, いずれの区でもトラップ間で差はなかった（Fig. 2).

試験 3. フェロモントラップにおけるフジコナカイガラ ムシ雄成虫誘殺消長およびフジコナカイガラ トビコバチ捕殺消長

岐阜市 $\mathrm{A}$ 固場に打けるフジコナカイガラムシ雄成虫の 誘殺は，調査期間を通じて認められ，両年とも 5 月上旬〜 6 月上旬に 2 山型の, 7 月中旬扎よび 8 月下旬〜 9 月中旬, 10 月下旬に 1 山型のピークが認められた. フジコナカイ ガラトビコバチの捕殺も調査期間を通じて認められ，両年 とも 5 月中下旬，6月中旬，8月上中旬，10月中旬にピーク が認められた.フジコナカイガラトビコバチ捕殺時期とフ 
Gifu

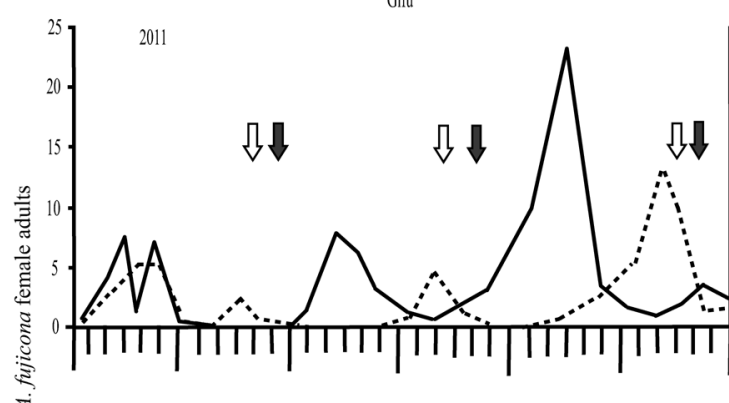

2011

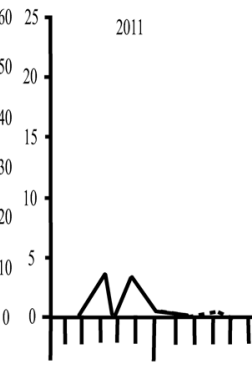

On

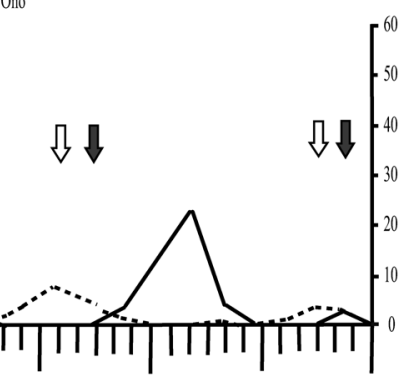

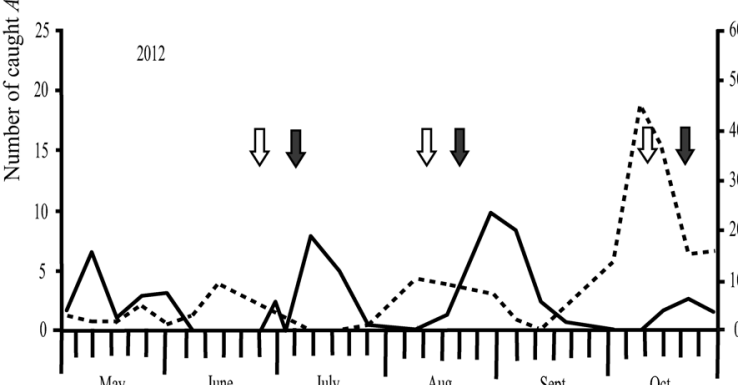

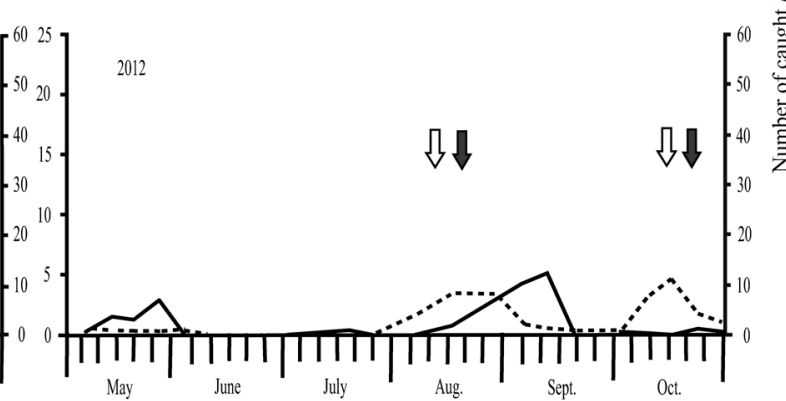

Fig. 3. The seasonal prevalence of P. kraunhiae male adults and A. fujikona female adults caught in a pheromone trap in two persimmon fields in Gifu city and Ono town. Solid and broken lines indicate the number of caught $P$. kraunhiae and $A$. fujikona, respectively. White and grey arrows indicate the predicted emergence time of second and third instar $P$. kraunhiae, respectively, with the effective accumulative temperature, using the average temperatures observed by AMeDAS in Gifu and Ibigawa.

ジコナカイガラムシ各齢期の出現予測時期を比較したとこ ろ, 6 月以降のフジコナカイガラトビコバチの捕殺ピーク は，フジコナカイガラムシ 2〜3 齢幼虫の出現予測時期ま たはその前にあった (Fig. 3).

大野町圃場に打けるフジコナカイガラムシ雄成虫の誘殺 数は，岐皁市と比較して少なく推移したが, 5 月中下旬, 7 月中旬, 9 月上中旬扎よび 10 月下旬にピークが認められた. フジコナカイガラトビコバチの捕殺ピークはフジコナカイガ ラムシ 2〜3 齢幼虫の出現予測時期と概ね一致した (Fig. 3).

\section{考察}

フジコナカイガラトビコバチ雌成虫は, フェロモント ラップには捕殺されるものの，ブランクトラップにはほと んど捕殺されず，覮乱区ではフェロモントラップにも捕殺 されなかった (Fig. 1，2）。一方，本種の雄成虫は，無処理 区に扔いてもフェロモントラップにほとんど捕殺されな かった。 これらのことは，フジコナカイガラトビコバチ雌 成虫が，フジコナカイガラムシの性フェロモンに誘引され たことを示している. トビコバチ科寄生蜂の 1 種 Anagyrus spec. nov. near pseudococciの雌成虫は, ミカンコナカイガ ラムシやPlanococcus ficus の性フェロモンをカイロモンと して宿主の探索に利用することが報告されている（Franco et al., 2008)．したがって，フジコナカイガラトビコバチの 雌成虫も，フジコナカイガラムシの性フェロモンをカイロ モンとして寄主探索に利用したため，フェロモントラップ に誘殺されたと考えられる.
フェロモントラップによるフジコナカイガラトビコバチ の誘殺消長は, 調査時期を通して 4 回程度のピークが確 認できた。 さらに 6 月以降の誘殺ピークはフジコナカイ ガラムシ 2 3 齢幼虫の出現予測時期またはその前にあっ た (Fig. 3). フジコナカイガラトビコバチは, フジコナカ イガラムシの 3 齢幼虫〜雌成虫に産卵するとされ（田中・ 小林，1971），福岡県ではこれらのステージが多く出現 する時期によく採集されると報告されている（手柴・堤, 2004).これらのことは, フジコナカイガラトビコバチが, 産卵対象として好適な齢期が出現する時期に先立ち, 2 3 齢幼虫が出現する時期に成虫数が増加している可能性を示 唆している.なお，同属の Anagyrus pseudococci (Girault) の発育期間は，宿主であるコナカイガラムシの約半分 で，年 7 8 回発生していると報告されている (Daane et al., 2004).また Arai and Mishiro (2004)は, やはり同属 の Anagyrus subalbipes Ishii の発育期間も同様であること に加え, 雌成虫の寿命は $25^{\circ} \mathrm{C}$ で 38 日程度と報告してい る。これらの報告は, フジコナカイガラトビコバチが含ま れる Anagyrus 属の寄生蜂は, 宿主のコナカイガラムシが 発生する期間には恒常的に発生している可能性を示唆して いる.したがって，今回の結果は，フジコナカイガラトビ コバチは産卵に好適な齢期のフジコナカイガラムシが増加 する時期に性フェロモンに反応して宿主探索をし，その結 果フェロモントラップに誘殺された可能性がある.フジコ ナカイガラムシの性フェロモンに対するフジコナカイガラ トビコバチの反応についてはまだ不明な点が多いが，今後 
解明が進むことにより，本種寄生蜂の活動時期や発生量を フェロモントラップによりモニタリングできる可能性があ ると考えられる.

一方，フジコナカイガラクロバチは誘引剤の有無に関係 なく，また交信攪乱条件下でも捕殺された (Fig. 1, 2). こ れらのことから，フジコナカイガラクロバチは性フェロモ ンに誘引されないと考えられた。 しかしながら，フジコナ カイガラクロバチの捕殺数は 100 頭以上とフジコナカイガ ラトビコバチよりも多く，偶然に捕殺されたとは考えにく い. 本種がトラップの色などに誘引された可能性があるた め，今後検討する必要がある.

また，今回確認されたフジコナカイガラムシ性フェロモ ンの寄生蜂 2 種に対する誘引性の違いは，フジコナカイガ ラムシの交信㩇乱条件下に扎いて，フジコナカイガラトビ コバチによるフジコナカイガラムシの密度抑制効果は期待 できないが，フジコナカイガラクロバチによる密度抑制効 果は期待できる可能性があることを示している。 今後，フ ジコナカイガラムシの総合防除法の確立にむけ，交信攪乱 条件下に打ける両種寄生蜂の寄主に対する寄生性を解明す る必要がある。

今回，フジコナカイガラムシの性フェロモントラップを 用いて本種の主要な寄生蜂 2 種の誘引性を確認した結果, フジコナカイガラトビコバチは性フェロモンに誘引される が, フジコナカイガラクロバチは誘引されないと考えられ た. また，フェロモントラップにより，フジコナカイガラ トビコバチの活動時期や発生量もモニタリングできる可能 性が示された。 今後, モニタリングに適したトラップの形 状や設置場所などを検討するともに，フジコナカイガラト ビコバチの性フェロモンに対する誘引特性を解明する必要 がある。

$$
\text { 摘 要 }
$$

フジコナカイガラムシ Planococcus kraunhiae (Kuwana) の寄生蜂であるフジコナカイガラクロバチ Allotropa subclavata (Muesebeck) とフジコナカイガラトビコバチ Anagyrus fujikona (Tachikawa) に対する性フェロモンの誘 引性を, フェロモントラップとブランクトラップを用いて 現地カキ園にて調査した。 フジコナカイガラトビコバチは フェロモントラップで捕殺されたがブランクトラップでは 捕殺されなかったこと，交信摫乱条件下ではいずれのト ラップにも捕殺されなかったことから，本種はフジコナカ イガラムシの性フェロモンに誘引され，カイロモンとして 利用していると考えられた，一方，フジコナカイガラクロ バチは，いずれのトラップでも同様に捕殺され，この傾向 は交信攪乱条件下でも変化しなかったことから，本種はフ ジコナカイガラムシの性フェロモンに誘引されないと考え られた。 また，フジコナカイガラムシのフェロモントラッ
プを用いてフジコナカイガラトビコバチの誘殺数の変化を 調査した結果，年 4 回の誘殺ピークがあり，6月以降の誘 殺ピークはフジコナカイガラムシの 2 3 齢幼虫の出現予 測時期またはその前にあった. このことから，フジコナカ イガラムシのフェロモントラップを用いることで, フジコ ナカイガラトビコバチも同時にモニタリングできる可能性 が示された.

\section{引用文 献}

Arai, T. and K. Mishiro (2004) Development of Allotropa citri Muesebech (Hymenoptera: Platygastridae) and Anagyrus subalbipes Ishii (Hymenoptera: Encyrtidae) on Pseudococcus cryptus Hempel (Homoptera: Pseudococcidae). Appl. Entomol. Zool. 39: 505-510.

Daane, K. M., R. D. Malalar-Kuenen and V. M. Walton (2004) Temperature-dependent development of Anagyrus pseudococci (Hymenoptera: Encyrtidae) as a parasitoid of the vine mealybug, Planococcus ficus (Homoptera: Pseudococcidae). Biol. Control 31: 123-132.

Franco, J. C., E. B. Silva, E. Cortegano, L. Campos, M. Branco, A. Zada and Z. Mendel (2008) Kairomonal response of the parasitoid Anagyrus spec. nov. near pseudococci to the sex pheromone of the vine mealybug. Entomol. Exp. Appl. 126: 122-130.

Gieselmann, M. J., R. E. Rice, R. A. Jones and W. L. Roelofs (1979) Sex pheromone of the San Jose scale. J. Chem. Ecol. 5: 891-900.

河合省三 (1980) 日本原色カイガラムシ図鑑. 全国農村教育協 会, 東京. 455 pp. [Kawai, S. (1980) Scale Insects of Japan in Colors. Zennoukyou, Tokyo. 455 pp.]

大政義久 (1990) カンキツに寄生するコナカイガラムシ類の防除 対策. 植物防疫 44: 256-259. [Ohmasa, Y. (1990) Ecology and control of the mealybugs on citrus trees. Plant Prot. 44: 256-259.]

Roelofs, W., M. Gieselmann, A. Cardé, H. Tashiro, D. S. Moreno, C. A. Henrick and R. J. Anderson (1978) Identification of the California red scale sex pheromone. J. Chem. Ecol. 4: 211-224.

澤村信生・奈良井祐隆 (2008) フジコナカイガラムシおよ びクワコナカイガラムシの発育と増殖能力に及ぼす温度 の影響. 応動昆 52: 113-121. [Sawamura, N. and N. Narai (2008) Effect of temperature on development and reproductive potential of two mealybug species Planococcus kraunhiae (Kuwana) and Pseudococcus comstocki (Kuwana) (Hemiptera, Pseudococcidae). Jpn. J. Appl. Entomol. Zool. 52: 113-121.]

柴尾学・田中寛 (2000) イチジクにおけるフジコナカイ ガラムシの発生消長と薬剤防除効果. 応動昆中国 42: 1-6. [Shibao, M. and H. Tanaka (2000) Seasonal occurrence of Japanese mealybug, Planococcus kraunhiae (Kuwana) on the fig, Ficus carica L. and control of the pest by insecticides. Jpn. J. Appl. Entomol. Zool. Chugoku Branch 42: 1-6.]

Sugie, H., M. Teshiba, Y. Narai, T. Tsutsumi, N. Sawamura, J. Tabata and S. Hiradate (2008) Identification of a sex pheromone component of the Japanese mealybug, Planococcus kraunhiae (Kuwana). Appl. Entomol. Zool. 43: 369-375. 
田中 学・小林正弘 (1971) フジコナカイガラムシ第 2 世代に 対する Allotropa subclavataの放飼効果. 九病虫研会報 17: 74-77. [Tanaka, M. and M. Kobayashi (1971) Liberation of Allotropa subclavata (Hymenoptera, Platygasteridae) at the second generation of Planococcus kraunhiae (Hemiptera, Pseudococcidae) in a persimmon grove. Proc. Assoc. Plant Prot. Kyushu 17: 74-77.]

手柴真弓・堤 隆文 (2004) カキを加害するフジコナカイガラ ムシの天敵相. 福岡農総試報 23：68-72. [Teshiba, M. and T. Tsutsumi (2004) The natural enemy complex of Planococcus kraunhiae injuring Japanese persimmons. Bull. Fukuoka Agric. Res. Cent. 23: 68-72.]

手柴真弓 ·清水信孝 ·澤村信生 ·奈良井祐隆 ·杉江 元 ·佐々 木力也・田端 純・堤 隆文 (2009) フジコナカイガラム シ Planococcus kraunhiae (Kuwana) に対する性フェロモン
成分による交信筧乱効果. 応動昆 53：173-180. [Teshiba, M. N. Shimizu, N. Sawamura, N. Narai, H. Sugie, R. Sasaki, J. Tabata and T. Tsutsumi (2009) Use of sex pheromone to disrupt the mating of Planococcus kraunhiae (Kuwana) (Hemiptera: Pseudococcidae). Jpn. J. Appl. Entomol. Zool. 53: 173-180.] 上野晴久 (1977） フジコナカイガラムシの生態と防除. 植物 防疫 31：159-164. [Ueno, H. (1977) Ecology and control of Planococcus kraunhiae (Kuwana). Plant Prot. 31: 159-164.]

Zada, A., E. Dunkelblum, F. Assael, M. Harel, M. Cojocaru and Z. Mendel (2003) Sex pheromone of the vine mealybug, Planococcus ficus in Israel: occurrence of a second component in a mass-reared population. J. Chem. Ecol. 29: 977-988.

Zhang, A. and D. Amalin (2005) Sex pheromone of the female pink hibiscus mealybug, Maconellicoccus hirsutus (Green): biological activity evaluation. Environ. Entomol. 34: 264-270. 